\title{
Parks and Problems in Colombia
}

\author{
Roger Perry
}

Colombia has a wealth of wildlife - including endangered species such as spectacled bear, mountain tapir, pudu and condor - a lot of still unexplored country, an impressive list of national parks and reserves, and an active national parks department. But there are many threats: a rapidly increasing population, haphazard settlement (with shifting 'slash and burn' cultivation), the increasing accessibility of formerly remote areas, the profitable trade in wild animals, and the lack of public interest in and support for conservation. Roger Perry has spent much time in South America, especially Colombia, and is a former Director of the Charles Darwin Research Station in the Galapagos Islands.

A short way above the old monastery of San Diego in Bogota is a new, circular building housing the Museum of Natural History of Colombia. Inside, in a descending spiral of floors, are depicted the main climatic zones in the country, each with its characteristic wildlife and scenery. Thus one passes from Andean peaks and moorlands, through the cloud forests, the steppe-like llanos and the vast rain forests of the Orinoco and Amazon, down to the long coastlines facing the Caribbean and the Pacific. Few visitors passing through these galleries can fail to be impressed with the immense diversity and natural richness of Colombia, which in particular has more species of birds than any other country in the world.

Over the past four years the Government of Colombia has given new emphasis to the creation of national parks and strengthened the administration of existing reserves. This impetus came with the establishment of the National Parks Department of the Institute for the Development of Natural Resources (INDERENA) and the delegation to this body of responsibility for all aspects of conservation in the country.

The list of established and projected reserves now makes impressive reading (see page 443), with all the main geographical regions represented. What is more open to doubt is how these parks will stand up to the consequences of social and economic change. The tide of development sweeping through Colombia today makes ever-increasing demands on the environment; population growth and settlement, the position of the indigenous Amerindian tribes, hunting and pollution are all factors exerting pressures inimical to the conservation of wildlife.

\section{People and Settlement}

'Spontaneous settlement' has always been a part of the Latin-American scene. To be able to settle on any unoccupied land has become a tradition, almost a right. A man claims a stretch of forest on the edge of a colonised area, and clears it to establish right of ownership. In some cases, as in the Macarena Reserve, settlement has its origin in civil unrest, but for the most part it is a natural consequence of population 
growth and the increased accessibility of underdeveloped regions. Year by year the rate of settlement is accelerating, and the completion of the Pan-American Highway and the link of the Trans-Amazon Highway from Manaos will herald an era of even more rapid development. This means that conservationists cannot derive unlimited comfort from the fact that vast areas of Colombia are still largely unexplored.

Uncontrolled settlement brings several dangers. Shifting cultivation, which involves clearing the forest, using the land for two to six years and then abandoning it to move to a fresh area, is an extraordinarily wasteful process and clearly a threat to wildlife. The combined effects of disturbance and hunting mean that species requiring large areas of forest over which to range - monkeys, trogons, toucans and parrots, to name a few - disappear very rapidly. Soil erosion and flooding follow the destruction of forest on over-steep slopes and along water courses.

Inaccessibility has been the key factor in preserving many of the areas now set aside as reserves. The considerations for siting a new road near the borders of a reserve, thus accentuating the problems of illegal settlement and hunting, need to be carefully weighed. The cost of patrolling a reserve adequately is at present above the budget of most conservation authorities, and once settlement begins it is extremely difficult to check. This is the situation now in the Macarena, the largest and in many ways most important reserve in Colombia, where INDERENA is faced with a community of five thousand colonists, firmly entrenched and occupying some ten per cent of the reserve. The only solution appears to be a major resettlement scheme with economic incentives in the form of compensation and development loans.

\section{Indigenous Amerindians}

The position of the indigenous Amerindian tribesman in this rapidly evolving scene is a complex one. His own attitude towards change is difficult to fathom and it is not surprising therefore that the subject is conveniently overlooked. The issue, nonetheless, is fundamental, not least because of the inadequate protection given to these people in the face of extending creole and mestizo* settlement. There are Amerindian tribes both in the national parks of the Santa Marta Mountains and in reserves now being established in the lowlands. Several tribes in the lowland forests east of the Andes have barely advanced beyond the stone age, and one previously unknown group was reported for the first time as recently as 1970 .

Where a tribe has advanced little beyond its primitive state there is obviously a very reasonable case for setting aside a reserve on its behalf. Where the tribe's territory extends into a national park it should presumably be regarded as an integral part of the life of the area and be offered the same measure of protection from outside interference as the wildlife. Unlike the settlers, Amerindians in their native state tend to attain a balance with their environment, partly by virtue of their semi-nomadic ways and sparse numbers, but mainly because hunting is solely for their immediate needs. The Tunebos, for instance, who inhabited the eastern slopes and cloud forests of the Cocuy Mountains, led a semi-migratory existence, moving from one established village to *Of mixed blood, including Indian. 

another at different seasons of the year. This meant that in each area game was given the opportunity to re-establish itself. But over the last two decades settlers have moved far into the territory of the Tunebos and this has resulted in the over-exploitation and decline of forest and all game species.

However well the tribes previously maintained the balance in their environment, the situation changes once they come into contact with civilisation; this seems to lead almost inevitably to a greater and unbalanced exploitation of resources. Excessive hunting on behalf of skin and animal dealers is only one aspect of this, but the disastrous effect on wildlife is obvious enough.

\section{Hunting and Trade}

The Amerindian tribes are being brought into the economic webs of dealers exploiting the wildlife of the forests. The range of species for which there is a market is a large one. Olivares lists the following that are collected either for their skins or plumage or for sale as cage-birds: egrets, parrots (Ara, Aratinga, Forpus, Brotogeris, Pionus, Amazona), humming-birds, quetzals, trogons, woodpeckers (Piculus, Dryocopus, Phloeceastes), cock-of-the-rock, umbrella-bird, cotingas, mockingbirds, thrushes, euphonias, tanagers (Anisognathus, Compsocoma, Thraupis, Cissopis), caciques, orioles, seed-eaters and finches. Even such an unlikely bird as the stilt is offered for sale as a cage-bird in the streets of Santa Marta, and if one were to spend a day or two visiting tourist centres the list would be found to be much longer. For each quetzal or cock-of-the-rock that arrives in the United States or Europe, writes Lehmann, fifty or more die in the hands of collectors and traders. Trophy hunting is responsible for a decline in the jabiru, king vulture, harpy eagle and Andean condor, in addition to the more obvious species. Hunting safaris increased sharply in the 1950s with the wider availability of light aircraft, helicopters and cross-country vehicles, but there is now the encouraging sign of growing criticism by many Colombians of such ruthless killing for sport.

\section{The Condor}

The condor (which appears in Colombia's coat of arms) is becoming increasingly scarce throughout virtually its entire range in the Andes. Although this is part of a general decline that has been going on for many years, due to environmental changes and shooting in sheep-raising areas, trophy hunting has played a part. As far as is known by INDERENA only a few pairs of condor survive in each of the Purace and Santa Marta national parks and at a few localities in Narino.

The Andean regions of Colombia have had a long history of human settlement and it is hardly surprising that many of the larger animals there should be declining. Besides the condor, the mountain tapir, spectacled bear, pudu, brockets (Mazama), white-tailed deer and the paca Agouti taczanowski are today in urgent need of protection. The Andean snipe and teal, torrent duck and several species of tinamou and guan are all mercilessly hunted; the cinnamon teal is now very scarce, and the southern pochard has already disappeared from areas where it was formerly abundant. 


\section{Crocodiles and Caimans}

The status of the Crocodilia in Colombia throws light on a rather different set of problems. Four genera in the country are represented by six species. Two, the black caiman and the Orinoco crocodile, are seriously threatened; and the other four are being exterminated in many if not most of the areas where they were formerly common. The main incentives for hunting are the demand for skins, particularly from overseas, and the mounting of young animals in a variety of grotesque ways for sale to tourists. In an attempt to halt the decline of the spectacled caiman, INDERENA, in 1968, restricted hunting to licenceholders and prohibited the killing of young below a certain size ( 1.20 metres). A further law, of July 1969, prohibited entirely the hunting and capture of the black caiman and the American and Orinoco crocodiles.

Any restriction is better than none, but it would be a mistake to believe that hunting has yet been curtailed to any real extent. Caiman hunting is a long established occupation and people near to subsistence level do not easily give up their livelihood. Attempts to enforce these laws can lead to violence. Probably what is first needed in the case of the caimans and crocodiles is a thorough survey of their status so that a balanced and objective statement of their plight can be presented to governments.* With this it should be possible to secure an internationally concerted policy to control the skin trade and smuggling. Only with international help to support the steps being taken by INDERENA inside Colombia is there much chance of saving these reptiles.

Laws exist for the protection of a number of other species including otters Pteronura brasiliensis, Lutra enudris and L. annectens, mountain tapir, manatees Trichechus manatus and $T$. inunguis, cotton-top marmoset, brockets Mazama americana and $M$. rufina, races of the white-tailed deer, and the pudu. Hunting of the roseate spoonbill, white and scarlet ibises, wood stork and jabiru has been prohibited in all territory administered by INDERENA, and in 1970 a trial close season was instituted to protect the capybara.

\section{Pollution}

It is inevitable that chemical pesticides and herbicides will continue to be used on a large scale in the developing regions of Colombia. Certainly the dangers of pollution are there, but the enormous benefits that pesticides have brought in making vast areas of the country more habitable and more productive encourages an attitude of laissez-faire.

\section{The Future}

Clearly, the task facing INDERENA is no light one. Development, often uncontrolled, is spreading to the remoter parts of the country and few of the existing national parks have entirely escaped its effects. The new settlers inevitably give little thought to protecting the wildlife, while ecology is not the main preoccupation of men prospecting for oil and minerals. Can conservation ideals be maintained against such pressures?

*This is now being done by Dr F. Medem for the Crocodile Group of IUCN. 
TERMITE MOUNDS in the savanna of northern Colombia, home of armadillos, ibises, crested screamers and burrowing owls Roger Perry

Fortunately Colombia had a nucleus of able naturalists, dedicated to conservation, even before the creation of INDERENA; now, with the new impetus, a whole series of study programmes is under way. It is accepted that unless there are some demonstrable returns from national parks it will not be possible to prohibit settlement in the immense areas that have been set aside. The dangers of access roads are appreciated but thought is nevertheless being given to creating facilities for visitors. The reserves in the high Andes can be reached without much difficulty but easy access to most lowland reserves is unlikely for some time to come. Yet the education of public opinion in the need for conservation does depend on enough people seeing what is at stake.

INDERENA is obviously right in trying to establish reserves in every major ecological zone of the country, but it is an uphill task to provide them with even the minimum staffs for effective protection and to defend these ambitious projects against the swelling tide of demographic and economic expansion.

\section{Acknowledgments}

The writer is most grateful to Dr. S. Max Franky and staff of the National Parks Department of INDERENA, to Mr. B. A. B. Curry, Dr. J. M. Idrobo and to Dr. F. Medem for their assistance and many courtesies in Colombia. Mr. G. T. Corley Smith and Mr. P. J. Hobbs very kindly gave their time and experience to assist with the

\section{PRINCIPAL REFERENCES}

CALA, P., 1970. Sobre la Explotación y Control de la Fauna Amazónica. Proc. II Simposio y Foro de Biología Tropical Amazónica, Ed. J.M. Idrobo, Bogotá: 145-151.

HARROY, J-P., 1971. United Nations List of National Parks and Equivalent Reserves. International Union for Conservation of Nature, Brussels.

LEHMANN, F. C., 1970. In Proc. of Symposium on the Avifauna of Northern Latin America, Smithsonian Cont. Zool., No. 26: 88-90.

MEDEM, F., 1968. El Desarrollo de la Herpetología en Colombia. Rev. Acad. Col., Vol. XIII, No. 50: 149-199.

MOLANO CAMPUZANO, J., 1964. Parques Nacionales, Monumentos y Reservas de la Naturaleza en Colombia. Bol. Soc. Geog. Col., Vol. XXII, Nos. 81/82.

OLIVARES, A., 1970. In Proc. of Symposium on the Avifauna of Northern Latin America, Smith. Cont. Zool., No. 26. 